\title{
MORTE IMPUNE, LUTO PROIBIDO: VIDA NUA E VIDA PRECÁRIA em Giorgio Agamben E Judith Butler
}

\author{
Reginaldo Oliveira Silva ${ }^{1}$
}

\begin{abstract}
Resumo: Giorgio Agamben tece a genealogia da "vida nua", no percurso que vai do homo sacer ao Muselmann, do primeiro paradigma da política ocidental à fabricação do morto-vivo, em Auschwitz, como vida insacrificável e impunemente matável. Judith Butler segue argumento semelhante, ao desenvolver o conceito de "vida precária", com o qual problematiza a separação entre vulnerabilidade universal e formas de produção da precariedade, a distinção entre vidas cujas perdas importam e as indignas de pranto e luto. A finalidade deste artigo consiste em aproximar as concepçōes dos dois autores, sob a hipótese de que, em ambos, trata-se da fabricação de vidas matáveis, sobre as quais pesa a proibição do luto.
\end{abstract}

Palavras-chave: Agamben. Butler. Vida nua. Vida precária. Vulnerabilidade.

\section{INTRODUÇÃo}

Escrito em 1995, Homo sacer: poder soberano e vida nua, de Giorgio Agamben, sustenta a tese de que a política ocidental, desde sempre, ocupouse de, e buscou capturar, a vida natural (Zoé), a qual se distingue da vida qualificada segundo um bem (Bios). A considerar as limitaçóes de Arendt e Foucault, para os quais, na política moderna, o foco incide muito mais sobre a $Z o e ́$, o filósofo italiano investe no exercício genealógico e sugere como primeiro paradigma político do Ocidente o Homo sacer, aquele que habita o limiar entre o profano e o sagrado. É assim que a vida natural adquire forma jurídica, como "vida nua", e aparenta ingressar na bios, num processo incessante que se desloca do direito romano para a Declaração dos Direitos do Homem, no século XVIII, até chegar à experiência do campo e do Estado de exceção, em Auschwitz.

\footnotetext{
${ }^{1}$ Docente na Universidade Estadual da Paraíba-UEPB, Campina Grande, PB - Brasil. (D) https:// orcid.org/0000-0003-1834-4541 E-mail: rgnaldo@uol.com.br
}

http://doi.org/10.1590/0101-3173.2020.v43n3.25.p339

\section{(i)}


No entanto, levar em conta o Homo sacer, capturado pelo direito, como forma de inclusão da mera vida na vida qualificada, sugere, também, manter aquilo que o caracteriza, a saber, a vida insacrificável e impunemente matatável. Nesse momento, encontra-se o paradoxo da política ocidental e a forma que assume e se consuma, na política moderna: a mera vida vem a ser incluída como vida que se pode matar, sem que o assassino venha a ser responsabilizado, ou seja, como vida nua.

Também aqui reside o ponto em que a vida nua pode ser pensada ao lado da vida precária, concepção inicialmente desenvolvida por Judith Butler, em Vida precaria: el poder del duelo y la violencia, de 2004, e Quadros de guerra: quando a vida é passivel de luto, de 2009. Ao partir do abismo existente entre uma definição universal da vida, que, a princípio, a todos inclui numa comunidade unívoca, e as formas de fabricação da vida não passível de luto, a pensadora traz para o contexto das reflexóes ética e política a condição "ontológica" da vulnerabilidade, mas também as ocasiões em que alguns grupos se tornam mais vulneráveis que outros, são privados da proteção das leis, da justiça e do luto público.

A reflexão que segue busca indagar se o que Agamben articula acerca da vida nua e as formas da sua captura na política ocidental não viria a coincidir com os meios com os quais a "vida precária" comum a todos é reservada a alguns grupos específicos. Se essa hipótese puder ser sustentada, outra dela emerge: se a vida nua, uma vez capturada pelo direito, define-se como insacrificável e impunemente matável, e a fabricação da condição de vida precária, submetida à violência e sem a cobertura do direito, se sobre ela não pesaria, ainda, a proibição do luto. Nessa linha, parece válido investigar se os conceitos de Agamben e Butler náo convergiriam exatamente no ponto em que se trata, em ambos, da fabriação de uma vida impunemente matável e, por isso mesmo, não merecedora do pranto coletivo. Se assim for, vida nua e vida precária seriam vidas "enquadradas" como não-humanas, sobre as quais pesam, consequentemente, a morte impune e o luto proibido.

A fim de dar conta desse propósito, primeiro será examinado o conceito de vida nua, segundo o percurso genealógico das investigaçóes de Agamben, mais precisamente em Homo sacer e $O$ que resta de Auschwitz: do homo sacer ao Muselmann: a vida nua não apenas é capturada pelo direito como impunemente matável, mas também emerge como impossibilidade de luto. Em seguida, nos textos indicados de Butler, serão examinados a vida precária e os meios de sua produção, nos quais se poderá observar, igualmente, 
o aspecto produtivo de vidas suscetíveis a toda sorte de violência e, em decorrência de, à indiferença em relação às suas perdas. Ao final, pretende-se aproximar os conceitos desenvolvidos pelos autores, conforme os aspectos da vida impunemente matável e da proibição do luto, o que torna vida nua e vida precária, apesar das diferenças entre os autores, aspectos de uma mesma relação política e ética com a vida, a qual baliza a experiência do presente.

\section{A Vida NUA E A Figura do Homo SACER}

De saída, convém pontuar a definição da vida nua, preliminar para a análise da genealogia do homo sacer. Em $A$ comunidade que vem, no capítulo onde se discute a eliminação das classes pela pequena burguesia, a qual, a fim de sobreviver ao niilismo, empreende a eliminação de toda e qualquer diferença, Agamben diz existir algo que escapa a tal propósito de destruiçáo. A saber, a morte seria o limite desse projeto, pois nela o pequeno burguês encontra a última expropriação: "a vida nua, o puro incomunicável" (AGAMBEN, 2013, p. 60).

A vida nua parece pertencer ao campo da indefinição, do que resiste, seja à apreensão pelo direito, seja à representaçáo. Definição interessante, pois a coloca entre a vida biológica ou natural e a vida humana, entre a mera vida e a vida historicamente narrável. $\mathrm{O}$ incomunicável que aí aparece diz tanto sobre as tentativas de apropriação como sobre a preservação do que o político sempre tentou capturar. No Epílogo a $O$ uso dos corpos, o filósofo recomenda novamente não confundir vida nua com vida natural, uma vez que ela é a consequência da captura da vida natural pelo dispositivo da exceção, o resultado de uma "vida que foi cindida e separada da sua forma" (AGAMBEN, 2017, p. 295) e, enquanto tal, ocupa o limiar entre vida natural e vida politicamente qualificada (AGAMBEN, 2017, p. 295). ${ }^{2}$

\footnotetext{
2 A fim de de acentuar a especificidade do conceito de Agamben, parece razoável fazer um breve inventário das elaboraçóes em torno da diferença entre vida natural e vida humana. Em $A$ condição humana, Hannah Arendt define a vida humana como o intervalo que se dá entre o aparecimento e o desaparecimento no mundo, cujo conteúdo pode ser narrado numa biografia. A autora sugere ser esta a bios de que trata Aristóteles, a qual, seguindo o filósofo grego, opóe-se à zoé, à "mera vida". Como o seu propósito é situar o labor nas ocupaçôes modernas, em seguida, distingue o processo biológico do processo de declínio e crescimento do mundo e, assim, aproxima o labor da vida biológica, ou seja, do processo biológico do organismo vivo. Têm-se aí dois tipos de vida, aos quais Arendt acrescenta dois processos diferentes: a vida humana, a bios, historicamente narrável, e a vida biológica, a zoé. Se, nesses breves apontamentos de Arendt, encontram-se dois tipos de vida, uma histórica e outra biológica, também em Foucault é possível indicar a mesma divisão, embora a intenção pareça ser diferente. Ao tentar situar o poder sobre os corpos, na política moderna, ao final do volume I de
} 
Puro incomunicável e consequência da captura da vida natural pela exceção, a vida nua estaria mais próxima, ainda, da experiência da vida privada, a qual, a partir de uma leitura de Guy Debord, como vida clandestina, acompanha os indivíduos sem que possa ser nomeada, mesmo que se tente comunicá-la por meio de fotos e documentos, no entender de Agamben (2017, p. 11), conforme era o projeto do pensador francês, a saber, conferir à vida privada uma dimensão política. Porque limiar, incomunicável e clandestina, a vida nua abriga certa perspectiva política do que escapa ao domínio e ao controle teológico-político: "a vida nunca é definida enquanto tal", frisa Agamben (2017, p. 15-16), "mas é todas as vezes articulada e dividida em bios e zoè, vida politicamente qualificada e vida nua, vida pública e vida privada, vida vegetativa e vida de relação".

Como se vê, Agamben, nessa leitura da obra de Guy Debord, ainda tem em mira a separação que Arendt e Foucault observam como determinante da política moderna; mantém a perspectiva da vida nua como algo que se interpóe entre vida natural, a mera vida ou vida biológica, e a vida histórica, a vida narrável e politicamente qualificada. A vida nua é o que resta, quando se busca ou definir a vida natural ou apanhá-la no aparato teológico-político ou na biopolítica, não tendo outro resultado senão a separação da vida privada da vida pública. A vida natural ou biológica possui uma forma, a qual se perde,

História da sexualidade, ele o faz, também, destacando a diferença entre o homem como animal vivo capaz de política e o homem animal, cuja política póe em questáo o seu ser vivo como animal. Tem em vista, portanto, a mesma separação com a qual Arendt trabalha para designar a atenção aos processos biológicos, por ela descritos na transição do trabalho para o labor. Tanto para um quanto para o outro, é essa separação que rege a política, e apenas teria se dado essa virada na direção da zoé, da mera vida, ou da vida animal. Em Walter Benjamin, em três textos, desenvolve-se o conceito de "mera vida" ou "vida natural". Em Origem do drama trágico alemão, situa a vida natural, que para ele é também a das obras e das formas, na pré e pós-história. Ou seja, náo se pode falar de vida natural, da mera vida, senão no enquadramento da História, ideia que ele reforça em "A tarefa do tradutor". O que de início parece ser uma proximidade com a compreensão de vida humana, em Arendt, a qual se distingue da vida natural, logo se dissipa ao se considerar, em "Para a crítica da violência", que a vida natural, aqui também nomeada vida orgânica, é aquela sobre a qual é exercida a violência do direito, seja para fundá-lo, seja para mantê-lo. Nesse breve esboço, reconhecidamente incompleto, já se pode enfatizar aspectos que conduziráo ao pensamento de Agamben e como ele constrói o conceito de vida nua. Ela é pensada mediante a comparaçẫo com uma vida mais condizente com a política ou que, até a modernidade, esteve fora do político; ela também é pensada quanto à sua relaçáo com a História e com o direito - quer como vida pré-histórica, quer como vida pré-jurídica, a vida natural é o que está fora e só se compreende nessa relação. De um modo ou de outro, nesses três autores, a vida natural constitui um fora, embora, em Arendt e Foucault, venha a se tornar a principal ocupação da política moderna. Vê-se, em Benjamin, a manutenção desse fora, e apenas pontua, em "Para a crítica da violência", que o direito viria a constituir uma forma de fazê-la entrar no domínio humano ou trazê-la para a História. O conceito de vida nua, conforme se desenvolve nos textos tardios, constituirá o resultado das tentativas de captura da vida natural nos dispositivos teológico, jurídico e biopolítico. 
quando se pretende incluí-la no direito ou na política, restando apenas das blosse Leben, a mera vida, constituindo-se o problema da política moderna, porém, igualmente, a contradição inerente à política ocidental.

Dessa compreensão de que a vida nua é o produto de uma separação, de uma vida separada da sua forma, pode-se examinar Homo sacer: o poder soberano e a vida nua, e investigar o incomunicável que escapa a toda intenção. É o que irá revelar a genealogia do homo sacer, as maneiras como se produz a vida nua, do direito à biopolítica, da declaração dos direitos humanos, no século XVIII, à experiência do campo. Nos esforços de separação, a vida nua se caracteriza como vida insacrificável e impunemente matável, mas também, ao estender a análise a $O$ que resta de Auschwitz, com a figura do Muselmann, da impossibilidade do luto.

Porque apreendida apenas na separaçáo, a vida nua constitui a estrutura da exceção, a qual Agamben depreende da relação da soberania com o ordenamento jurídico. À soberania cabe tanto proclamar o estado de exceção quanto suspender o ordenamento jurídico, paradoxalmente, permanecendo fora e dentro do direito. A figura do soberano seria uma "espécie de exclusão [...] um caso singular, que é excluído da norma geral” (AGAMBEN, 2010, p. 24), a qual não sugere um estar fora da relação com a norma, antes, conservase como suspensão da norma; uma situação em que algo primeiro é excluído para, em seguida, ser incluído, sem que este deixe de ser excluído. Como forma originária do direito, a exceção sugere que aquilo que não pode ser em nenhum caso incluído vem a ser inserido sob a forma da exceção (AGAMBEN, 2010, p. 31), a qual virá a subsistir na forma do bando, do banimento da comunidade.

Se o poder soberano, ao instaurar a exceção, captura no seu gesto a vida nua, essa tentativa aparece pela primeira vez no direito romano, sob a figura do homo sacer, cuja definição sugere aquele que foi julgado por um delito e não pode ser sacrificado, contudo, se alguém o matar, não comete por isso homicídio. A contradição inerente ao homo sacer implica que, "enquanto sanciona a sacralidade de uma pessoa, autoriza (ou mais precisamente, torna impunível) a sua morte" (AGAMBEN, 2010, p. 74). Assim é, em virtude da ambiguidade do sagrado, da sacratio, a qual indica ao mesmo tempo o que é digno de veneração e suscitante de temor. Quanto a esta última, a impunidade do homem sacro se deve a que o sacro já está desde o início entregue aos deuses, todavia, não é aí que reside o problema. A questão que se póe consiste em indagar por que ele pode ser impunemente matável (AGAMBEN, 2010, p. 76). 
Como figura do sagrado, deste, o homo sacer traz consigo duas características: a da impunidade da matança e a da exclusão do sacrifício. Como foi consagrado aos deuses, fez a passagem do profano para o sagrado, foi "simplesmente posto para fora da jurisdição humana, sem ultrapassar para a divina" (AGAMBEN, 2010, p. 83). Mantendo-se, por isso, como exceção do profano e do sagrado, não pertencendo nem a um nem ao outro, ele será "incluído na comunidade na forma da matabilidade" (AGAMBEN, 2010, p. 85). Daí a sua vida se assemelhar à vida sacra, cuja condição é a de uma vida submetida a uma violência que não é nem sacrifício nem homicídio, nem execução de uma condenação nem sacrilégio. Em sendo a soberania "a esfera na qual se pode matar sem cometer homicídio e sem celebrar um sacrifício", a vida sacra, ou a vida nua, será "a vida capturada nesta esfera" (AGAMBEN, 2010 , p. 85). Ou seja, no limiar entre sagrado e profano - nos termos acima utilizados, entre zoé e bios, vida natural e vida qualificada.

Se, até então, interessa a Agamben sustentar a tese de que o homo sacer constitui a primeira tentativa de captura da vida nua pelo aparato teológicopolítico e, por conseguinte, que não é privilégio da política moderna dela se ocupar; se, dessas investigaçóes, resulta que a vida nua se constitui como exceção, a inclusão de uma exclusão anteriormente levada a cabo, configurada doravante como insacrificável e impunemente matável; e se, daí, ela vem a ser um desvio da separação da vida biológica de sua forma, a fim de dar lugar à vida humanamente qualificada - quando o autor retorna ao problema da modernidade e agrega ao aparato teológico-jurídico a biopolítica, a estrutura orignária da exceção se consolida em dois acontecimentos os quais atualizam a relação de exceção, a saber, o habeas corpus, em 1679, e a Declaração dos diretos humanos, de 1789, mas também a produção do Muselmann, nos campos de concentração. Um percurso subterrâneo do rio da biopolítica, no dizer de Agamben (2010. p. 118), que antecede o século XX.

Nesse sentido, é preciso observar na genealogia do homo sacer que o propósito de captura da vida natural resulta no surgimento da vida impunemente matável. É por esse caminho que se torna possível sustentar a hipótese de que o conceito de Agamben, vida nua, e o de Butler, vida precária, convergem, quanto à produção de vidas sobre cujas perdas pesam a impunidade e a impossibilidade do luto. Porém, antes de adentrar nos textos da autora, convém explorar como o italiano analisa a atualidade do homo sacer e da vida nua, na figura do Muselmann, e de que maneira, com este, à vida impunemente matável agrega-se o luto impossível. 


\section{O MUSELMANN E A ATUALIDAde DO Homo SACER: DA MORTE IMPUNE AO LUTO PROIBIDO}

A fim de conferir a essa tapeçaria genealógica a devida consistência metodológica, o que dela se pretende e se torna possível, a saber, que, na modernidade, a vida impunemente matável não se reduz a apenas uma experiência histórica específica, convém fazer agumas consideraçôes sobre o uso metodológico do paradigma. A motivação que mobiliza Agamben ao paradigma, desenvolvido em Signatura rerum: sobre o método, surge da necessidade de melhor esclarecer o uso que faz de Homo sacer e Muselmann. É isso que, logo de início, defende o italiano: trata-se de tomar dois fenômenos históricos e, deles, "constituir e tornar inteligível um contexto mais amplo" (AGAMBEN, 2019, p. 9). Para ficar, por enquanto, nesses inícios, se, com o Homo sacer, ele forja a figura predominante na política ocidental, com o Muselmann, que atualiza aquele, pode o filósofo pensar a impunidade do assassinato na modernidade. Nos propósitos do presente artigo, se, com o primeiro se insere na política a vida impunemente matável, com o outro, a esta se acrescenta a impossibilidade do luto, como se verá mais adiante.

Em que pese a querela entre Foucault e Kuhn, e apoiando-se na mudança estratégica do francês, a saber, a de abandonar a concepção tradicional de poder em favor dos seus dispositivos concretos, Agamben (2019, p. 19), a fim de demonstrar a especificidade do uso de paradigamas, recorre ao panopticon. Trata-se de um fenômeno histórico singular, o qual, para além de um modelo arquitetônico, permite definir "a inteligibilidade do conjunto do qual faz parte e que, ao mesmo tempo, constitui” (AGAMBEN, 2019, p. 21). Com o panopticon, torna-se possível compreender o caráter disciplinar que o poder adquire na modernidade e, no mais, denuncia-se "o limiar pelo qual ele [o poder] transpassa para as sociedades do controle” (AGAMBEN, 2019, p. 21).

Nesses termos, o Homo sacer, fenômeno histórico do direito romano, ao mesmo tempo em que constitui parte das tentativas de captura da vida natural, serviria de modelo para compreender, na política ocidental, fenômenos semelhantes - um exemplo singular que define um contexto histórico mais amplo, o limiar que permite sair da virtualidade do propósito de dominar a vida natural e constituir a vida humanamente qualificada. Nessa mesma medida, pode ser pensada a vida nua, a qual se materializa com a sacratio, mas também ilustra toda tentativa de separação de vidas impunemente matáveis. No entender de Agamben (2019, p. 22), como caso individual, o paradigma "é isolado do contexto do qual faz parte apenas na medida em que 
ele, exibindo a própria singularidade, torna inteligível um novo conjunto, cuja homogeneidade é constituída por ele mesmo". É esse o movimento feito pelo filósofo italiano, ao evocar o Homo sacer como paradigma da política ocidental e ao atualizá-lo na figura do Muselmann.

No entanto, não se trata aí de constituir um universal, pois é próprio do paradigma, que segue muito mais a analogia, a metáfora e o exemplo, anular a dicotomia entre particular e universal, tornando inoperante a oposição "ou A ou B". Investindo, antes, na indiscernibilidade, não se rege por regras previamente estabelecidas, ao contrário, em conformidade com os juízos estéticos de Kant, é dele que faz brotar a regra. Nesse sentido, nele não se trata "simplesmente de constatar certa semelhança sensível, mas de produzila através de uma operação" (AGAMBEN, 2019, p. 30), ou seja, "o paradigma nunca está dado, mas se gera e produz [...] mediante um 'mostrar' e um 'expor'” (AGAMBEN, 2019, p. 30). Eis, portanto, nas palavras de Agamben (2019, p. 41), onde podem ser situados o Homo sacer e o Muselmann, a saber, em vez de remetê-los a uma causa ou origem histórica, são eles paradigmas "cujo escopo era tornar inteligível uma série de fenômenos" (AGAMBEN, 2019, p. 42).

Como paradigma, o Homo sacer explica o movimento da política ocidental na apropriação da vida natural, a qual termina por produzir a vida impunemente matável e insacrificável; como movimento que se desenvolve no tempo, configura-se, nos campos de concentração, na forma de Muselmann, ou seja, como vida cujo assassinato nem será punido, menos ainda digno de luto. Nesses termos, torna-se mais plausível a argumentação sobre a linha de continuidade genealógica entre Homo sacer e Muselman, e como, neste último, se introduz a problemática do luto, ensejando cumprir a ambição deste artigo, a saber, defender que Agamben e Butler expressam de diferentes formas o paradigma da morte impune e do luto proibido, eliminando a fronteira entre vida e morte.

No tocante à biopolítica, como dispositivo de captura da vida nua na modernidade, a qual sucede os dispositivos teológico e jurídico, dois aspectos devem ser ressaltados. Com as declaraçóes dos direitos humanos e o apelo ao nascimento como forma de inserção na política, salienta Agamben (2010, p. 124), representa-se "aquela figura original da inscriçẫo da vida natural na ordem jurídico-política do Estado-nação”, o artifício moderno que permite incluir a vida nua nas decisóes políticas. Ao lado desses direitos, teria lugar o outro aspecto da biopolítica, a saber, a identificação da vida que merece morrer, sobretudo porque ameaça os viventes, o que faz da vida nua não apenas 
uma "categoria definida, mas habita o corpo biolítico de cada ser vivente" (AGAMBEN, 2010, p. 135).

A vida indigna de ser vivida é, por excelência, um conceito político, fazendo parte da "metamorfose da vida matável e insacrificável do homo sacer", sublinha Agamben (2010, p. 137). A vida sem valor "se coloca sobretudo na intersecção entre a decisão soberana sobre a vida matável e a tarefa assumida de zelar pelo corpo biológico da nação, e assinala o ponto em que a biopolítica converte-se em tanatopolítica" (AGAMBEN, 2010, p. 137-138). Tratase de "decidir o ponto em que a vida cessa de ser politicamente relevante" (AGAMBEN, 2010, p. 138), ou seja, de que o poder soberano tanto se estende à vida nua quanto decide sobre o ponto em que uma vida deixa de ter valor, portanto, exerce a decisão sobre a morte.

Se está certa a tese de Agamben, de que a biopolítica constitui o telos da história política do Ocidente, o campo é o seu absoluto configurar-se, a experiência contemporânea da inclusão da vida nua, tão imprescindível, nesse propósito, a ponto de ele ser o "paradigma do espaço político no ponto em que a política torna-se biopolítica e o homo sacer se confunde virtualmente com o cidadão" (AGAMBEN, 2010, p. 167). Ademais, será no campo que o homo sacer se produz, e se atualiza, como Muselmann, como vida cujo luto será impossível. Enquanto na origem do homo sacer, e pelas características da sacratio, a vida nua se configura como vida insacrificável e impunemente matável, a qual habita o limiar entre o profano e o sagrado, com o Muselmann, a vida nua se manifesta, em acréscimo, como vida não passivel de luto.

No sentido de fechar esse círculo e, desse modo, aproximar a genealogia de Agamben das investigaçóes de Butler, de O que resta de Auschiwitz, interessam o Muselmann e a fabricação do morto-vivo, nos campos de concentração. $\mathrm{O}$ recorte se explica em função do tema aqui sugerido, uma vez que, da perspectiva política que abriga o homo sacer, nesse último texto, Agamben traz para a problemática da vida nua a dimensão ética. Assim como o campo constitui a atualidade genealógica da captura da vida nua, o Muçulmano será atualidade da saga biopolítica do homo sacer, do qual se pode pensar a experiência presente da vida impunemente matável.

"Muçulmano" é o apelido dado aos doentes de desnutrição, os quais, vistos de longe, pareciam árabes em oração (AGAMBEN, 2008, p. 51). Em citação de É isto o homem?, de Primo Levi, muçulmanos são os "submersos", a "multidão anônima", não-homens que marcham em silêncio, nos quais se 
apagou a centelha divina. "Presença sem rosto", muçulmano é o "homem macilento, cabisbaixo, de ombros curvados, em cujo rosto, em cujo olhar, não se possa ler o menor pensamento" (AGAMBEN, 2008, p. 52). O termo vem de Muselmann, cuja explicação mais provável vem da palavra árabe Muslim, que significa "quem se submete incondicionalmente à vontade de Deus" (AGAMBEN, 2008, p. 52), por conseguinte, aquele que perdeu qualquer vontade ou consciência (AGAMBEN, 2008, p. 53). Ele marca o "umbral em que o homem passa a ser não-humano" (AGAMBEN, 2008, p. 55), por isso, é "um ser indefinido, no qual não só a humanidade e a não-humanidade, mas também a vida vegetativa e a de relaçáo [...] a vida e a morte transitam entre si sem solução de continuidade" (AGAMBEN, 2008, p. 56). Como produto de Auschwitz, são "cadáveres ambulantes", "mortos-vivos", "homens-múmias".

Daí deriva outro aspecto da experiência do campo, a saber, a preocupação com o continuar ou não sendo humano, ante a qual se recomenda afastar-se do muçulmano, por medo de se tornar um "igual”. Não apenas ele configura uma transformação, também, nesta, constitui uma ameaça aos que ainda se consideram humanos, o que traz consigo uma impossibilidade ética e, ao mesmo tempo, um novo paradigma para a ética. Logo, evita-se dele falar, "como se o silêncio fosse no momento a única atitude adequada para quem habita além de qualquer ajuda" (AGAMBEN, 2008, p. 70). Como morto-vivo e homem-múmia, representa uma nova forma de experiência com a morte, ou de limiar entre vida e morte. Hesita-se chamar de morte a sua morte, porque já não é mais morte, sendo este "o horror especial que o muçulmano introduz no campo e que o campo introduz no mundo" (AGAMBEN, 2008, p. 76-77). Uma morte burocrática que muito se distancia da morte natural, cuja consequência mais imediata é a da impossibilidade dos rituais fúnebres, por conseguinte, do luto. Depois de Auschwitz, o muçulmano persiste como morto entre os vivos, portanto, como larva da qual não se fez a despedida, habitando o mundo dos vivos como "não-homem que se apresenta [...] como homem, e o humano que é impossível dissociar do inumano" (AGAMBEN, 2008, p. 87).

Como desvio das tentativas de captura da vida biológica pelas máquinas de controle, seja a iniciativa teológica, seja jurídica ou biopolítica, a vida nua que, de início, se caracteriza, a partir do primeiro sucesso da captura, o homo sacer, como insacrificável e impunemente matável, a forma que a ela agrega na experiência do extermínio será a do luto impossível, quando o Muselmann ocupa o lugar da sacratio. Morte impune e luto impossível seriam, por 
conseguinte, os contornos de uma vida que mais e mais prolifera, à medida que avança a biopolítica no Ocidente.

\section{A PRODUÇÁO DA VIDA PRECÁRIA E A PROIBIÇÁO DO LUTO}

Se a genealogia de Agamben remete a um começo e traça os deslocamentos dessa origem, de modo a indicar as técnicas com as quais, no presente, o mecanismo que engendra a vida impunemente matável e enlutável se mantém na senda da repetição, não é de todo impertinente buscar sustentar que, neste ponto de chegada, o que o italiano conclui sobre a vida nua se aproxima das análises de Judith Butler sobre a vida precária. Morte impune e luto impossível - em Butler, luto proibido - seriam noçóes que permitem aproximar a pensadora judia do filósofo italiano. A fim de argumentar a hipótese, segue-se com o exame de dois textos de Butler, conforme acima indicados.

A começar Vida precaria: el poder del duelo y la violência; nele, Butler achama a atenção, incialmente, para o 11 de Setembro como ponto de partida de uma reflexão sobre uma política que leve em conta a vulnerabilidade e a agressão. Além disso, é do interesse da autora indagar sobre em que condiçóes se distinguem as vidas que valem a pena das que nada valem - as que estáo protegidas da vulnerabilidade comum das que, por conta dessa mesma vulnerabilidade, são submetidas à violência, mas também das perdas que são choráveis daquelas que carregam o peso do luto proibido.

No capítulo 2, "Violência, luto, política", ela analisa a dimensão da vida política, a exposição à violência e cumplicidade com a violência, da qual se segue a vulnerabilidade da perda e o trabalho de luto. A perda constitui um "nós", a marca de uma forma de comunidade que tem no corpo o seu algo em comum (BUTLER, 2006, p. 46), caráter social, o qual, de imediato, contraria a reivindicação de direitos sobre o corpo. Por isso, dois seriam os pilares que organizam uma comunidade da vulnerabilidade: os corpos expostos ao outro e o luto como possiblidade, em virtude dessa exposição. No seu dizer: "o corpo supóe mortalidade, vulnerabilidade, práxis: a pele e a carne nos expóem ao olhar dos outros, mas também ao contato e a violência” (BUTLER, 2006, p. 52). E, logo, completa: "o corpo tem uma dimensão invariavelmente pública. Constituído na esfera pública como um fenômeno social, meu corpo é e não é meu" (BUTLER, 2006, p. 52). Trata-se aí de uma dimensão orignária, adverte 
Butler (2006, p. 53), cuja negação significaria negar as condiçóes sociais do corpo em nome da autonomia.

Nesse sentido, ela inclui a centralidade política do luto, no seu entender, uma forma "terrível de expor o caráter originalmente vulnerável do homem em relação a outros seres humanos [...] um modo pelo qual a vida mesma pode ser eliminada pela ação deliberada de outro" (BUTLER, 2006, p. 54). No entanto, se a vulnerabilidade que caracteriza o corpo é, de início, postulada como perspectiva política, porque permite pensá-la em termos de violênica e agressão, o fato de algumas comunidades estarem mais propensas à violência exige que se coloque a pergunta pelas condiçôes em que certas vidas são mais vulneráveis e estão mais submetidas à agressão que outras. Ao que parece, o projeto ético-político proposto por Butler tem de fazer a travessia das formas de produção de vidas matáveis, ou seja, o aspecto ontológico que possibilita sustentar uma dimensão política não pode prescindir de um exame das "formas radicalmente diferentes de distribuição da vulnerabilidade física do homem em todo o planeta" (BUTLER, 2006, p. 58).

A vulnerabilidade constitutiva de todos, aqui, aparece como algo de produzido e fabricado por determinadas circunstâncias, as quais merecem que sobre elas se reflita. A violência deve ser pensada a partir da distinção entre vida que vale a pena, a vida humana, e vida que não pode ser considerada como humana - na mesma medida em que, tão logo a Declaração dos direitos do homem de 1789, compreendida por Agamben como escalada da inclusão da Zoé na Bios, afirme a vida, por meio do nascimento, como valor político, também dá margens para distinguir as vidas dignas de serem vividas das que sequer serão consideradas vidas.

A resposta a esse questionamento virá no capítulo 5, "Vida precária", onde Butler enfatiza a dimensão ética da vulnerabilidade e se aproxima mais da definição da vida precária, bem como das condições que perfazem a proibição do luto. Ela retoma o caráter público do corpo e coloca a pergunta sobre a demanda (ou a interpelação). Aqui, o corpo não apenas se constitui como estando exposto à violência física, sobretudo entra em questáo a violência da interpelação, que, se não o elimina, circunscreve-o num quadro normativo, anterior à formação da vontade, conforme frisa Butler (2006, p. 165). A demanda moral é uma imposição que, de fora, atinge o sujeito, sem que este possa se defender, uma interpelação à qual ele responde involuntariamente. Daí ela sugerir o exame da relação entre as demandas e a autoridade moral. 
Para iniciar a investigação, a autora se apoia na concepção de "rosto", de Lévinas, logo em seguida apontando os seus limites. Da mesma maneira que ela parte da vulnerabilidade da vida como condição comum e depois indaga sobre as vidas submetidas à violência, por conta dessa mesma vulnerabilidade - também em relação ao rosto, esse percurso metodológico se dá: o rosto como mandato ético não pode ser pensado senão na relação com o rosto produzido, o qual torna possível o assassinato e a proibição do luto. O rosto é o "modo de responsabilidade mais básico"; é o outro "pedindo-me que não o deixe morrer", e que deixar seria tornar-se cúmplice de sua morte, portanto, anuncia o "Não matarás!" (BUTLER, 2006, p. 167). Diz-se ainda do rosto: ele "não fala, mas o mandamento 'não matarás!' transmite sem dúvida o que o rosto significa" (BUTLER, 2006, p. 167). O rosto denuncia a "extrema precariedade do outro" (BUTLER, 2006, p. 169), a precariedade da vida mesma. A definição mais contraditória do rosto consiste em que ele é, como precariedade do outro, também o que desperta o desejo de matar (BUTLER, 2006, p. 169). A questão consiste em idagar como se deve compreender que o rosto, apelo para não matar, também seja o que impele ao assassinato.

Essa contradição tem alcance significativo, ensejando pensar a ética como a luta interna que o homem trava para náo matar, para não cometer o assassinato, mesmo que se trate de autodefesa, do exercício do direito de preservar a própria vida, em caso de ameaça: o rosto "transmite agonia, vulnerabilidade, ao mesmo tempo que uma proibição divina contra o assassinato" (BUTLER, 2006, p. 170). Na verdade, desperta o desejo de matar, o primeiro impulso "frente à vulnerabilidade de outro", o qual baliza a interdição ética. Daqui, Butler coloca dois problemas, os quais partem dessa ambiguidade da mensagem que o rosto transmite, a saber, o da representação e do discurso. Assim, pode ela questionar a ética do rosto, de Lévinas, e problematizar a fabricação de rostos com os quais não se pode estabelecer qualquer identificação, por conseguinte, deles "ouvir" o mandato ético da interdição do assassinato.

O problema do rosto seria consoante com o problema do discurso ou da linguagem, consequentemente, com o da representaçáo. E, nesse ponto, emerge a mesma divisão que ela já anunciara quanto à vulnerabilidade da vida. Ou seja, o problema ético que o rosto sugere, se, por um lado, é interdição do assassinato e, por outro, desperta o desejo de matar, a questão que se põe é sobre a produção de rostos que náo expressam a vulnerabilidade. Aqueles que são representados estấo menos suscetíveis à desumanização; os que não o são, 
serão facilmente considerados como não-humanos. E aqui a mídia adquire papel preponderante na produção de rostos que nada comunicam, senão a autorização para a violência, uma forma de "suspender a precariedade comum da vida" (BUTLER, 2006, p. 179). Os rostos produzidos pela mídia, em vez de anunciar a precariedade, são emoldurados de tal maneira que neles não se vê precariedade alguma, antes, dá-se o efeito contrário: tem-se a personificação do mal por meio de uma "cara" (BUTLER, 2006, p. 178). "A cara oculta o som do sofrimento humano e a proximidade que devemos ter a respeito da precariedade da vida mesma”, acrescenta Butler (2006, p. 181), bem como "essa cara que se retrata como capturada pelo mal náo é precisamente um rosto humano" (BUTLER, 2006, p. 181). Assim, torna-se impossível a identificação, e o rosto aparece apenas como o que serve para desumanizar e como autorização para a violência.

Além do papel dos meios de comunicação, Butler ressalta que, em virtude dos esquemas de inteligibilidade, ou esquemas normativos, os quais estabelecem de antemáo o que é humano e não-humano, distingue-se a vida vivível e a morte lamentável. Há formas de enquadramento com as quais e por meio das quais são propiciadas as identificaçôes. Estas funcionam na produção de imagens do que é humano ou não, por conseguinte, também do que é inumano. Trata-se, por vezes, de subtrair a imagem, "de modo que ali nunca houve uma vida nem houve uma morte" (BUTLER, 2006, p. 183). É uma prática consoante com duas formas do poder: uma que produz uma identificação simbólica do rosto com o inumano; e outra que funciona apagando qualquer humanidade, de sorte que, ali, se nada há de humano, não houve vida, por conseguinte, não haverá assassinato (BUTLER, 2006, p. 183). Se o humano é algo que surge no campo visual, como rosto, noutro momento, no campo público, faz-se a exclusão dessa imagem.

Os sistemas normativos determinam o que é humano, por isso, indicam as arestas da identificação ética, as quais também servem de base para a representação do rosto e das caras, nos meios de comunicação. $\mathrm{O}$ não-humano será pontuado ou por meio de uma representaçáo direta ou simplesmente por omissão. No dizer de Butler (2006, p.181), “certas vidas e mortes ou são irrepresentáveis ou são representadas sob as formas que voltam a inscrevê-las dentro da guerra, uma vez mais". A consequência disso é que, além de não serem consideradas como vidas humanas, ou pela representação do mal ou como recusa de representação, o luto dessas vidas também será proibido - se não houve vida nem houve morte, não há porque existir perda nem luto. 
Trata-se aí de um processo de desumanização, que tanto coloca vidas sob a mira da violência quanto determina que delas não se pode constituir luto algum.

\section{As VIDAS ENQUADRADAS COMO NÃO HUMANAS E A PROIBIÇÁO DO LUTO}

Já aí aparecem os contornos da produção de vidas precárias: a representação, no discurso e nas mídias, os sistemas normativos que reproduzem as formas do poder e da política. Esses conceitos serão desenvolvidos e mais bem estruturados em Quadros de guerra: quando a vida é passivel de luto?, onde Butler dá continuidade às reflexôes de 2004 e melhor evidencia os "modos culturais de regular as disposiçóes afetivas e éticas por meio de um enquadramento seletivo e diferenciado da violência” (BUTLER, 2016, p 13). Para tal, foi necessário, de início, distinguir a precariedade comum a todos e a condição precária produzida por certas formas de poder, para, em seguida, enfrentar o problema dos enquadramentos, em seus aspectos espitemológico e ontológico. Se o que é considerado vida depende de um poder que atua ou para regular a aparição ou, através de seus mecanismos, produzir o que seria a vida, a tarefa investigativa indaga sobre "em que condiçóes torna-se possível apreender uma vida, ou um conjunto de vidas, como precária, e em que condições isso se torna possível ou mesmo impossível” (BUTLER, 2016, p. 14-15).

O problema do qual parte Butler consiste, portanto, nessa separação das formas de apreensão da vida ou da destinação de certos grupos à violência, enquanto outros estariam mais sujeitos às agressóes, algo que se eliminaria por intermédio de uma nova ontologia corporal, que "implique em repensar a precariedade, a vulnerabilidade, a dor, a interdependência, a exposição, a subsistência corporal, o desejo, o trabalho e as reivindicaçóes sobre a linguagem e o pertencimento social" (BUTLER, 2016, p. 15). O que Butler compreende por ontologia condiz com a noção de a priori histórico, esquema de compreensão predominante numa dada época histórica, o qual serve, por seu conteúdo universal, de referência para o conhecimento ou reconhecimento. É este o sentido de a ela ser necessário compreeender que a precariedade está ligada à noção política de condição precária. Logo, no seu entender, ser a condiçáo precária "o ponto de partida para repensar a ontologia corporal" (BUTLER, 2016, p. 16). 
Se se trata de tomar a precariedade como constituidora de uma comunidade, do que é comum a todos, não se pode deixar de investigar em quais condiçôes reconhecer essa precariedade se torna impossível. No seu entender, a capacidade epistemológica de apreender uma vida depende da produção dessa vida segundo normas e, nesse sentido, a ontologia produz quadros epistemológicos de apreensão da vida e, por conseguinte, fornece as bases do reconhecimento ético. É nessa linha que ela passa a examinar os conceitos nucleares da sua análise: apreensão, reconhecimento e enquadramento. Esse caminho é importante, pois dele se torna possível colocar a questão que interessa: o que torna uma vida passível de luto e outras náo. Apreender uma vida é diferente de reconhecê-la, embora ambas se deem como formas de conhecimento. $\mathrm{Na}$ apreensão, apenas ocorre o conhecimento de uma vida, mas não necessariamente o reconhecimento de uma vida por outra vida. Para que este último aconteça, seria necessário indagar as condiçóes gerais de reconhecimento.

A cena do reconhecimento, em que dois indivíduos se encontram, um diante do outro, supóe a anterioridade das condiçóes de reconhecimento, as quais "preparam ou modelam um sujeito para o reconhecimento" (BUTLER, 2016, p. 19). Na cena, alguém não só apreende o outro, o conhece, como com ele se identifica e reconhece, mas, por outro lado, o que na cena se desenrola é mais que ambos e os inere: entram em jogo as condiçóes que tornam o reconhecimento possível. Butler separa esses dois tempos, a fim de indicar que o problema do reconhecimento e da apreensão de uma vida não se desvincula das condiçóes anteriormente postas, ou seja, as condiçôes determinadas para que o reconhecimento e a apreensão se realizem. Assim, o reconhecer não é algo que uma pessoa decide ou náo fazer, antes, trata-se de uma potencialidade que a todos implica.

Se o reconhecimento depende das condiçôes de ser reconhecido, estão igualmente condicionados à inteligibilidade ou ao "esquema (ou esquemas) histórico geral que estabelece os domínios do cognoscível” (BUTLER, 2016, p. 21), ou seja, ao a priori histórico. Nessa perspectiva, as normas são condição de reconhecimento, contudo, estâo atreladas à inteligibilidade que as condiciona e produz; elas estão aí e delas se dá o reconhecimento, mas elas são produzidas segundo alguns esquemas que tornam possível apreender uma vida. Pode-se, portanto, dizer que as normas surgem de certos esquemas as quais tornam inteligíveis o que é uma vida, e, por isso, preparam o reconhecimento. Noutros termos, os esquemas são anteriores às normas e as fundam, estas que, por sua 
vez, são anteriores ao reconhecimento e determinam os comportamentos dos indivíduos ali onde eles se defrontam uns com os outros.

É aqui que tem lugar a noção de "enquadramento" ${ }^{3}$ e sua ambiguidade constitutiva. Três são os sentidos que a autora elabora sobre o to be framed, o "ser enquadrado", a saber: a moldura de um quadro, ser incriminado por um crime e cair numa armação incriminadora, cujo sentido comum segue o propósito da moldura: estabelecer marcos interpretativos. Entretanto, ao contrário da moldura de quadros, nos dois últimos, trata-se de "emoldurar" açóes com vistas a apontar um culpado, cujo melhor exemplo são os fenômenos midiáticos.

É nesse percurso, do reconhecimento aos enquadramentos, que se pode pensar a apreensão da precariedade da vida. Nas palavras da autora, "apreendemos a precariedade da vida através dos enquadramentos à nossa disposição" (BUTLER, 2016, p. 28). À medida que se esclarecem as formas de apreensão da vida, também se evidenciam os modos de separação da vida passível de luto das que não o são, ou seja, "como a comoção é produzida por essa estrutura do enquadramento" (BUTLER, 2016, p. 29). Porque a intenção é política e ética, a fim de estabelecer para estas o lugar da comoção, necessário será traçar o perfil do que vem a ser o reconhecimento da precariedade ou como torná-la imanente às normas que precedem o reconhecimento.

Do ponto de vista ontológico, vida precária é condição "compartilhada da vida” (BUTLER, 2016, p. 30), no entanto, há casos em que é produzida. A precariedade se carateriza pela finitude da vida e o que esta implica: o viver socialmente na dependência de outros, mas também o estar submetido à morte e, por conseguinte, à possibilidade da perda e do luto. Viver significa ainda depender das redes e condiçôes sociais (BUTLER, 2016, p. 42), daí ser "a vida precária [...] condição de estar condicionado" (BUTLER, 2016, p. 43); se "não há vida sem a necessidade de abrigo e alimento" (BUTLER, 2016, p. 45), logo, "não há vida sem redes sociais mais amplas de sociabilidade e trabalho" (BUTLER, 2016, p. 45). A essa "universalidade" se opõem as condições de precariedade criadas em certos regimes políticos ou sistemas normativos, os quais tanto promovem os enquadramentos da vida passível de luto quanto fomentam a proibição do luto público, a produção de vidas não enlutáveis,

\footnotetext{
3 A noção de "enquadramento", segundo a própria Butler $(2016,262)$ admite, apoia-se em La vérité en peinture, de Jacques Derrida, e Frame analyses: an Essay of the Organization of Experience, de Irving Goffman.
} 
deixadas à sorte da violência e do assassinato, do sofrimento, do subemprego, da privação dos direitos (BUTLER, 2016, p. 50).

A esse aspecto Butler (2016, p. 50) nomeia "condição precária", porque politicamente induzida e produzida em determinadas formaçôes políticas, as quais engendram formas de poder e dominação, cujo primeiro sinal é a situação de dependência própria do corpo. "A condição compartilhada da vida conduz não ao reconhecimento recíproco, mas sim à exploração específica de populaçóes-alvo", assinala Butler (2016, p. 53), "de vidas que não são exatamente vidas, que são consideráveis destrutiveis e náo passiveis de luto". Para além da precariedade comum a todos, a vida precária se caracteriza igualmente pela existência de "populaçóes perdíveis", que podem ser sacrificadas, "precisamente porque foram enquadradas como já tendo sido perdidas e sacrificadas" (BUTLER, 2016, p. 53); como ameaçam a vida humana, não são vistas "como populaçóes vivas que necessitam de proteção contra a violência do Estado, a fome e as pandemias" (BUTLER, 2016, p. 53); ao contrário, são "comunidades não exatamente reconhecidas como tais, sujeitos que estão vivos, mas que ainda não são considerados 'vidas'” (BUTLER, 2016, p. 54).

À pergunta sobre quais vidas são passíveis de luto e quais não são, em quais enquadramentos, fomentados por sistemas normativos, os quais ou dizem que vidas têm ou não valor, quais são consideradas como vida e quais não podem ser, deve-se levar em conta não somente o papel da mídia, mas também o das formaçóes políticas, quando fornecem vidas enquadradas como não vidas. Nas palavras de Butler (2016, p. 85): "os enquadramentos normativos estabelecem de antemáo que tipo de vida será digna de ser vivida, que vida será digna de ser preservada e que vida será digna de ser lamentada”. Essa divisão da vida em vidas protegíveis e vidas matáveis, que os enquadramentos impóem, condiciona os julgamentos e afetos morais, de modo que se instauram dificuldades de apreensão da precariedade, constituindo-se, portanto, em que pese a dimensão política, impedimentos ao reconhecimento do outro, no campo da ética. Consequentemente, tem-se aí a separação que impossibilita o reconhecimento do outro, de sorte que integre os afetos, porém, sobretudo, traz a marca da proibição do luto.

\section{CONSIDERAÇÓES FINAIS}

Seja na perspectiva dos campos de concentração, com Agamben, seja na dos enquadramentos normativos, com Butler, por analogia, vida nua e 
vida precária são vidas produzidas - e aqui é preciso considerar, em Butler, a separação entre a ontologia da preciariedade comum e as políticas de produção de vidas precárias. A hipótese de que os autores estão a falar de um mesmo fenômeno, da mesma experiência contemporânea das relaçóes intersubjetivas, da comunicação de uns com os outros, parece de todo plausível, apesar de, em cada um, o ponto de partida ser diferente. O Muselmann, como figura mais recente da saga biopolítica do Homo sacer, da vida insacrificável e impunemente matável, resulta em que, nele, não apenas se trata de tentativas de apropriação de uma vida banida do mundo humano. O fato de com ele não haver, por conta do temor do seu destino, comunicação, menos ainda identificação, não somente traduz o mecanismo biopolítico de apreensão da vida, como, principalmente, rompe com a fronteira entre vida e morte. $\mathrm{O}$ banimento do espaço humano, ao final, implica, consequentemente, o baimento da linguagem e de qualquer reconhecimento ético possível. Como morto-vivo, também dele não se faz luto, pois, se não há morte, não faz sentido que haja perda, muito menos pranto.

A genealogia de Agemben faz o percurso dessa transformação, definindo, com o conceito de vida nua, o estado de coisas atual, no qual a vida parece não se distinguir da morte. Ele desvenda a atualidade da vida impunmente matável, cujo paradigma deveio Muselmann. Nessa linha, a vida precária poderia ser compreendida como um dos aspectos da vida impunemente matável e insacrifícável do Homo sacer, cujo luto se torna impossível, em virtude da indistinção entre vida e morte, quando aquele assume a forma do Muselmann. A atualidade genealógica do Homo sacer, que acrescenta ao impunemente matável e insacrificável do Homo sacer o luto impossível, o Muselmann, permite afirmar que Judith Butler explora, com outros termos e noutras perspectivas, mas também expande, a compreensão da vida separada das suas formas. Se é permitido dizer que o Muselmann é um capítulo da longa trajetória do Homo sacer, a vida precária, fabricada sob certas formas de poder e de enquadramentos normativos, inscreve-se nesse lugar em que não apenas a vida se confunde com a morte, porém, sobretudo, há vidas das quais não se pode fazer luto.

Levando-se em conta a produção do morto-vivo, em Auschwitz, ou os enquadramentos normativos que determinam quais vidas são vidas e quais não o são, o que está aí em jogo, numa e noutra perspectiva, é que a relação com a vida se transformou e, consequentemente, com a perda. Vida nua e vida precária são diferentes esforços conceituais, com o fim de designar o 
paradigma da vida impunemente matável, insacrificável e não chorável, uma vida separada, e separável, de qualquer forma, seja esta jurídica, seja política ou ética. Essa experiência teve início nos campos de concentração e constitui, doravante, a condiçáo primeira dos enquadramentos normativos que obscurecem o reconhecimento de certas vidas como vidas e, por fim, como passíveis de luto.

SILVA, R. O. Unpunished death, forbidden mourning: naked life and precarious life in Giorgio Agamben and Judith Butler. Trans/form/ação, Marília, v. 43, n. 3, p. 339-360, Jul./Set., 2020.

\begin{abstract}
Giorgio Agamben weaves the genealogy of "naked Life", on the path that goes from Homo sacer to Muselmann, from the first paradigm of Western politics to the manufacture of the undead in Auschwitz, as an unexpendable and unpunishable killing life. Judith Butler follows similar argument in developing the concept of "precarious life", with which problematizes the separation between universal vulnerability and forms of production of precariousness, the distinction between lives whose losses matter and the unworthy of weeping and Mourning. The purpose of this article is to approximate the conceptions of the two authors, under the assumption that in both it is the manufacture of killing lives, on which it weighs the prohibition of grief.
\end{abstract}

Key words: Agamben. Butler. Naked life. Precarious Life. Vulnerability.

\title{
REFERÊNCIAS
}

AGAMBEN, Giorgio. Homo sacer: o poder soberano e a vida nua I. Tradução Henrique Burigo. Belo Horizonte: Editora UFMG, 2010.

AGAMBEN, Giorgio. Meios sem fim: notas sobre a política. Tradução Davi Pessoa Carneiro. Belo Horizonte: Autêntica, 2015.

AGAMBEN, Giorgio. Signatura rerum: sobre o método. Tradução Andrea Santurbano e Patrícia Peterle. São Paulo Boitempo, 2019.

AGAMBEN, Giorgio. O que resta de Auschwitz: o arquivo e a testemunha. Tradução Selvino J. Assmann. São Paulo: Boitempo, 2008.

AGAMBEN, Giorgio. Profanaçóes. Tradução Selvino José Aussmann. São Paulo: Boitempo, 2007.

AGAMBEN, Giorgio. O uso dos corpos. Tradução Selvino J. Aussmann. São Paulo: Boitempo, 2017. 
AGAMBEN, Giorgio. A comunidade que vem. Tradução Claudio Oliveira. Belo Horizonte: Autêntica, 2013.

BUTLER, Judith. Quadros de guerra: quando a vida é passível de luto? Traduçáo Sérgio Tadeu de Niemayer Lamarão e Arnaldo Marques da Cunha. Rio de Janeiro: Civilização Brasileira, 2016.

BUTLER, Judith. Vida precaria: el poder del duelo y la violencia. Buenos Aires: Paidós, 2006.

Recebido: 10/08/2019

Aceito: 24/02/2020 
SILVA, R. O. 